\title{
Land cover change and land use suitability analyses of coastal area in Bantul District, Yogyakarta, Indonesia
}

\author{
SARAH AFSHOLNISSA ${ }^{*}$, ENDANG HERNAWAN, TIEN LASTINI \\ School of Life Sciences and Technology, Institut Teknologi Bandung. Labtek XI, Gedung SITH-ITB, Jl. Ganesa 10, Bandung 40132, West Java,. \\ Indonesia. Tel.: +62-22-2511575. Fax.: +62-22-253 4107, ‘email: afshols@yahoo.com
}

Manuscript received: 4 January 2019. Revision accepted: 30 April 2019.

\begin{abstract}
Afsholnissa S, Hernawan E, Lastini T. 2019. Land cover change and land use suitability analyses of coastal area in Bantul District, Yogyakarta, Indonesia. Biodiversitas 20: 1475-1481. Shrimp farming in the southern coast of Bantul District is considered to be the cause of environmental degradation, decline of mangrove association due to logging for land conversion to shrimp pond and also considered to be the cause of agricultural land for crops around the shrimp pond. The purpose of this study was to identify land use change and analyze the land suitability for shrimp farming, agriculture, and mangrove plant associations. Identification of land use was done using ENVI 5.3. The study identified 34.88 ha (3.16\%) empty ponds, 20.97 ha (1.90\%) active ponds and as much as 91.93 ha $(8.31 \%)$ land used for agriculture. The identification of land use change using Google Timelapse revealed a dominant land conversion of sandy soil and mangrove plant area into shrimp ponds in 2007 and continue to increase from 2011 to 2015. Land suitability was evaluated using ArcGIS 10.5 with an overlay method. The results revealed that 634.82 ha area of the land was suitable for shrimp ponds and 84.32 ha area were suitable for non-paddy agriculture. Lands suitable for paddy field were about 148.58 ha, and that for mangrove plant association was 616.42 ha. Spatially, coastal area of Bantul District was dominantly suitable for shrimp farming.
\end{abstract}

Keywords: Land suitability, land use change, mangrove association, rice, shrimp farming

\section{INTRODUCTION}

Indonesia is the world's largest archipelagic country with about 17.508 islands (of which 6000 are inhabited), $81,000 \mathrm{~km}$ of coastline, and the world's fourth most populous nation (247.5 million in 2017). The total area that can potentially be used for aquaculture development is about 2,606,000 ha. Aquaculture plays an important role in reducing unemployment. In 2003, there were 2284208 households involved in the aquaculture industry, representing around $40 \%$ of the total number of people employed in the fisheries sector (FAO 2014). According to MMAF (2013), the main commodities in Indonesia's aquaculture are tilapia (947,000 metric tons), shrimp (623,000 metric tons) and milkfish (575,000 metric tons). Tilapia and shrimp are the targeted aquaculture production for key aquaculture species for 2019 set by the national government. Worldwide demand for fishery products has always been increasing over the years. With regards to aquaculture, one of the main species of interest in Indonesia is shrimp, of which vannamei is the dominantly farmed species (IPSOS 2016). According to IPSOS (2016), $75 \%$ of estimated proportion of total production is concentrated in Java, Lampung and South Sulawesi.

In Java, one of the shrimp aquaculture development center in Yogyakarta. Three main aquaculture farming centers in Yogyakarta are Bantul, Kulon Progo, and Gunung Kidul Districts. Currently, shrimp aquaculture in Bantul faces some problems. Ufrianto et al. (2016) indicated that shrimp farming in Bantul can be divided into three periods of development, i.e., period I (1980-1989), period II (1989-2012), and period III (2012-present). Land use conflicts do occur between shrimp farming and other sector agriculture, protected area, borders of beach and river, and road. The main problem that may trigger many conflicts includes the uncertainty in regulations related to spatial coastal areas, both in policy and implementation.

Resolution of conflict between shrimp farming and other sectors can be done through consensus approach, conflict resolution through the cultural dimension and resolution of cultural conflicts. Intensive shrimp farming, according to Asbar (2007) has the potential impact on the aquatic environment due to the organic material waste load received such as nutrient enrichment, eutrophication, hypoxia, and sedimentation. The rapid development of shrimp farming should be controlled or well-managed to fit the carrying capacity of the environment.

District Environment management Service of Bantul (2014) revealed that shrimp farming in coastal area caused the decline of mangrove association plant such as Casuarina equisetifolia. Mangrove association plant is plants that can adapt and tolerate environmental factors that are ecologically extreme in coastal areas, namely high salinity. The land that consists of mangrove association was converted into shrimp farmland, whereas mangrove association is important as wind barrier. Shrimp farming was responsible for the global destruction of significant amount of mangrove areas. Estimates from countries which have done historical data permit assessment indicated that $35 \%$ of mangrove cover had been lost, with just over half attributed to conversion for aquaculture (Valiela et al. 2001). Besides, data from Province Environmental 
Management Service of Yogyakarta (2016) revealed that shrimp farming in coastal area also threatened the spawning habitat of sea turtle. In 2003, 1500 eggs of turtles were found, while in 2015 only 46 eggs were found. The problems were also worsened by agriculture sector in coastal area. Conflicts between agriculture farmers and shrimp farmers are still occurring and no solution has been made yet. According to the fishermen, their fish catch has been totally declining since the start of shrimp farming in the region. Many of the local and national level mass media released that the main problems in Bantul's shrimp farming is related to the management, which urgently requires improvement. The shrimp farmers cannot manage their land properly and they are now facing bankruptcy. Some ponds were just abandoned and neglected, and others were rented to investors. The empty ponds neglected by the farmers are now being utilized by agriculture farmers to cultivate crops such as corn, red onion, rice, etc. The above description shows that South Coast area of Bantul is potential for many sectors. Therefore, this research aimed to identify the land cover change and land use suitability for each sectors using Geographic Information System (GIS).

\section{MATERIALS AND METHODS}

\section{Research site}

The research site was the shrimp farming areas in the southern coast of Bantul District, Yogyakarta Province. Bantul District covers most of the southern areas of Yogyakarta Province. Geographically, Bantul District laid between $07^{\circ} 44^{\prime} 04 \quad-08^{\circ} 00^{\prime} 27^{\prime \prime}$ South Latitude and $110^{\circ} 12^{\prime} 34$ "-110³1'08" East Longitude (Bappeda Bantul 2013). Historically, the south coast of Bantul has been used for ponds in the past years, resulting in mangrove destruction. Nowadays, however, most of the farm activities are in an inactive condition, and the farmers have begun to shift their agricultural activities to rice fields and other seasonal crops. The Bantul District Government wants a re-plan for the land use in this region.

\section{Materials}

The materials used in this research included personal computer installed with ArcGIS 10.5 and ENVI 5.3, Global Positioning System (GPS), soil sampling ring, aluminum foil, shovel, knife, hoe, camera, stationery, maps, and saturated image from Worldview at 2 June 2017 (1:25,000 scale).

\section{Data collection method}

The primary data included $\mathrm{pH}, \mathrm{C}$-Organic, $\mathrm{N}, \mathrm{C} / \mathrm{N}$, $\mathrm{P}_{2} \mathrm{O}_{5}, \mathrm{Ca}, \mathrm{Mg}, \mathrm{K}, \mathrm{Na}$, salinity and spatial data that were collected through terrestrial survey while community perception was identified by using a questionnaire. The secondary data was collected from several governmental organizations. Step by step procedures was specified with determined research objects, gathered data and information, literature study, map interpretation (FAO 1983; Maroeto et al. 2013; Djaenuddin et al. 2003; Pusat Penelitian Tanah 1983; Sanchez 1976; and preparing materials needed. Then, land cover was identified by using ENVI 5.3 software with maximum likelihood classification methods. The classifications were divided into 10 classes, i.e., shrimp pond; home garden; paddy field; river; main road; empty pond; vegetable crop field; harvested crop field; residence area; sea.

The output of land use identification was raster data. Raster data was then changed into vector data using GIS 10.5 using conversion tools, from raster to polygon (Indriastiti 2016). Land cover change was identified visually through Google Timelapse from 1984-2016 (Khoiri 2013). Survey and observation were then carried out, followed by ground-checking in research target area. Raster data from ENVI 5.3 was confirmed by degree of agreement using Kappa analysis (Altman 1991). The steps were continued with determination of sample point and sampling of soils for laboratory analysis. Analysis of soil properties included $\mathrm{pH}$, salinity, C-Org, $\mathrm{N}, \mathrm{C} / \mathrm{N}, \mathrm{P}_{2} \mathrm{O}_{5}, \mathrm{~K}$, $\mathrm{Ca}, \mathrm{Mg}, \mathrm{K}$, Na, Cation Exchange Capacity (CEC), saturation base (FAO 1976). Land suitability classes were also determined and classified according to land suitability parameters using ArcGIS 10.5.

Soil variables that used were soil physical properties (soil type, slope, climatology) and soil chemical properties (pH; salinity; C-Org; $\mathrm{N}$; C/N; $\mathrm{P}_{2} \mathrm{O}_{5} ; \mathrm{K} ; \mathrm{Ca} ; \mathrm{Mg} ; \mathrm{K} ; \mathrm{Na}$; Cation Exchange Capacity (CEC); saturation base) (FAO 1976). Land characteristic was compared according to various references (FAO 1983; Maroeto 2013; Djaenuddin, 2003; Sanchez 1976). Maps of land suitability were then created for shrimp pond, mangrove association, paddy, and non-paddy agriculture; crops using GIS (Manjela 2010), followed by verification by the community. Land suitability map was shown to community around coastal area to make a decision for coastal land use. Questionnaire was used for verifying the community perceptions (Heriyanto 2014). The last step was development of land suitability map based on community verification for decision making in land use of South Coast area of Bantul (Manjela 2010).

\section{Data analysis}

Land use analysis of coastal area in Bantul was carried out by using a saturated image from WorldView2 year 2017. Analysis was done using a maximum likelihood classification to obtain the percentage of land use. Ground checking and ground-truthing were carried out to confirm the accuracy of data analysis. Cohen's kappa coefficient was used in ground-checking and ground-truthing to measure inter-rater agreement for qualitative items. Cohen's kappa measures two raters (ENVI and actual ground), each classifies items into mutually exclusive categories. This analysis is conceptually simpler to evaluate agreement between items or raters. The value of degree of agreement was based on Altman (1991).

Land suitability class was determined by Weighted Overlay operation of each land suitability criterion variable. Variables in analyzing the suitability of the land were classes of land suitability determined by summing up each variable of each land characteristic land, after obtaining the total sum of each land suitability criterion variable. The variables used are presented in data on Table 1. 
Table 1. Characteristics of land for highly suitable class (S1) of paddy, non-paddy, shrimp pond, and association mangroves

\begin{tabular}{lcccc}
\hline \multicolumn{1}{c}{ Land/water characteristics } & S1-paddy & S1-non paddy & S1-shrimp pond & $\begin{array}{c}\text { S1-association of } \\
\text { mangrove }\end{array}$ \\
\hline Land Slope (\%) & $<3$ & $<8$ & $0-3$ & $0-3$ \\
Rainfall (mm/year) & $>1500$ & $500-1200$ & $<1500$ & 1685 \\
Soil Type & Alluvial & Latosol & Alluvial & Entisol \\
Soil pH & $5.5-7$ & $6-7$ & $6.5-8.5$ & $5-8$ \\
CEC & $>16$ & $>16$ & - & - \\
Base Saturation & $>50$ & $>35$ & - & - \\
C-Org (\%) & $>1.2$ & $>1.2$ & $1.5-2.5$ & - \\
Total N & medium & high & medium & - \\
P2O5 & high & very high & high & - \\
Salinity (Ds/M) & $<2$ & $<2$ & $0.015-0.025$ & - \\
Water brightness & - & - & $0.30-040$ & - \\
water pH & - & - & $75-8.5$ & - \\
\hline
\end{tabular}

Both soil physical and chemical characteristics were used in the overlay methods. Class in land suitability was categorized according to FAO (1975) using Atlas Format Procedures. Classes and the parameters used in suitability analysis of each land use is also presented in Table 1.

Public perception is needed for decision making of an output. Likert scale response forms included: Strongly Agree (SS), Agree (S), Neutral (N), Disagree (TS), Very Disagree (TSS). A total of 20 respondents were randomly selected from community members living around the coastal area of Bantul District. Each answer has a weight value, therefore, it can be calculated by the formula as the followings:

$$
\text { Index }(\%)=\text { Total score } / \mathrm{Y} \times 100
$$

\section{RESULTS AND DISCUSSION}

Bantul District is a fertile area, because of its soil layer, irrigation, territorial integrity and its location at the southern end of rivers which accumulate volcanic mud and humus deposited from the North. Natural conditions of Bantul are suitable for agriculture, therefore, most of the people of Bantul District are farmers (Bappeda Bantul 2013). Besides, coastal areas of this district are also used for aquaculture activities.

\section{Land cover change}

The coastal areas of Bantul District were mainly used for agriculture and aquaculture. Image processing of land cover of coastal area employing ENVI software automatically classified the landcover as shrimp ponds with active and non-active categories. In addition, land cover was dominantly agricultural land, mostly rice and non-rice (vegetable) farmings. Percentage of land cover for ponds was $5.06 \%$ (3.16\% of inactive ponds and $1.90 \%$ of active ponds). Agricultural land occupied $8.31 \%$ of the land cover of which $5.95 \%$ was for rice field and $2.36 \%$ was for nonrice fields. Kappa analysis revealed that degree of accuracy through ground-truthing with and obtained the result of agreement for shrimp farm of 0.70 (good) and result of agreement's degree for agriculture equal to 0.60 (moderate). Data in raster format was then converted to vector using GIS by eliminating pixels with an area of $<6.25$ ha to obtain a more accurate land use map (Figure 1).

Current land use in South Coast area of Bantul District is already converted. Formerly, according to BLH Bantul District (2014), South Coast area of the district was dominated by agriculture, sand dunes as spawning ground for turtles, and mangrove associations as wind barrier. Lands formerly planted with trees such as casuarina, acacia, kleresede and wild plants are now lost replaced by shrimp ponds. The massive development of shrimp farming due to high public interest potentially cause conflict between shrimp farmers and agricultural farmers. Changes in the function of coastal areas into shrimp ponds have the potential to cause land use conflicts and environmental impacts that directly affect local communities. The potential conflicts arising from the development of shrimp farming were influenced by perceptions and knowledge of the local community. Negative perceptions of these business developments potentially cause resistance from or conflict between communities.

Visually, land use change in coastal area of Bantul District can be seen through Google Timelapse until 2016 (Figure 2).

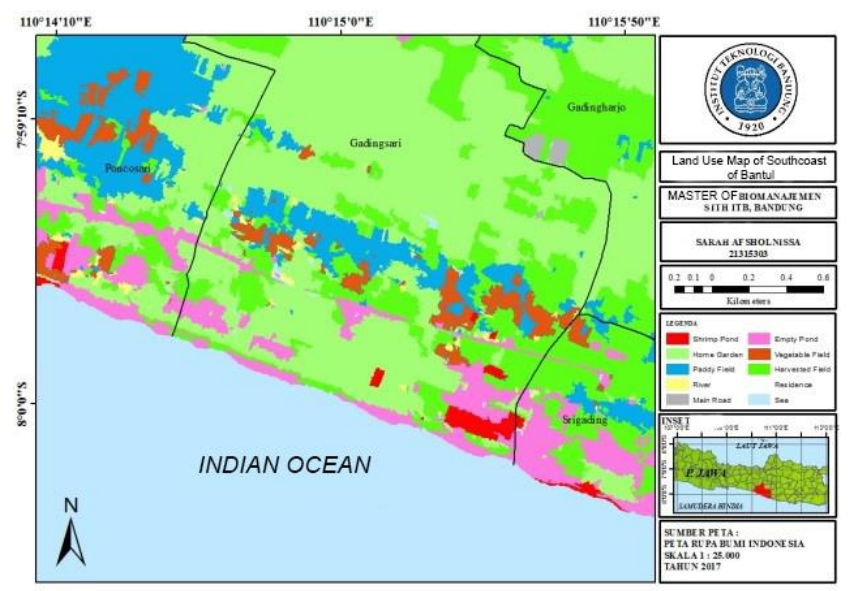

Figure 1. Land cover of South Coast area of Bantul District, Yogyakarta, Indonesia that processed using ENVI 


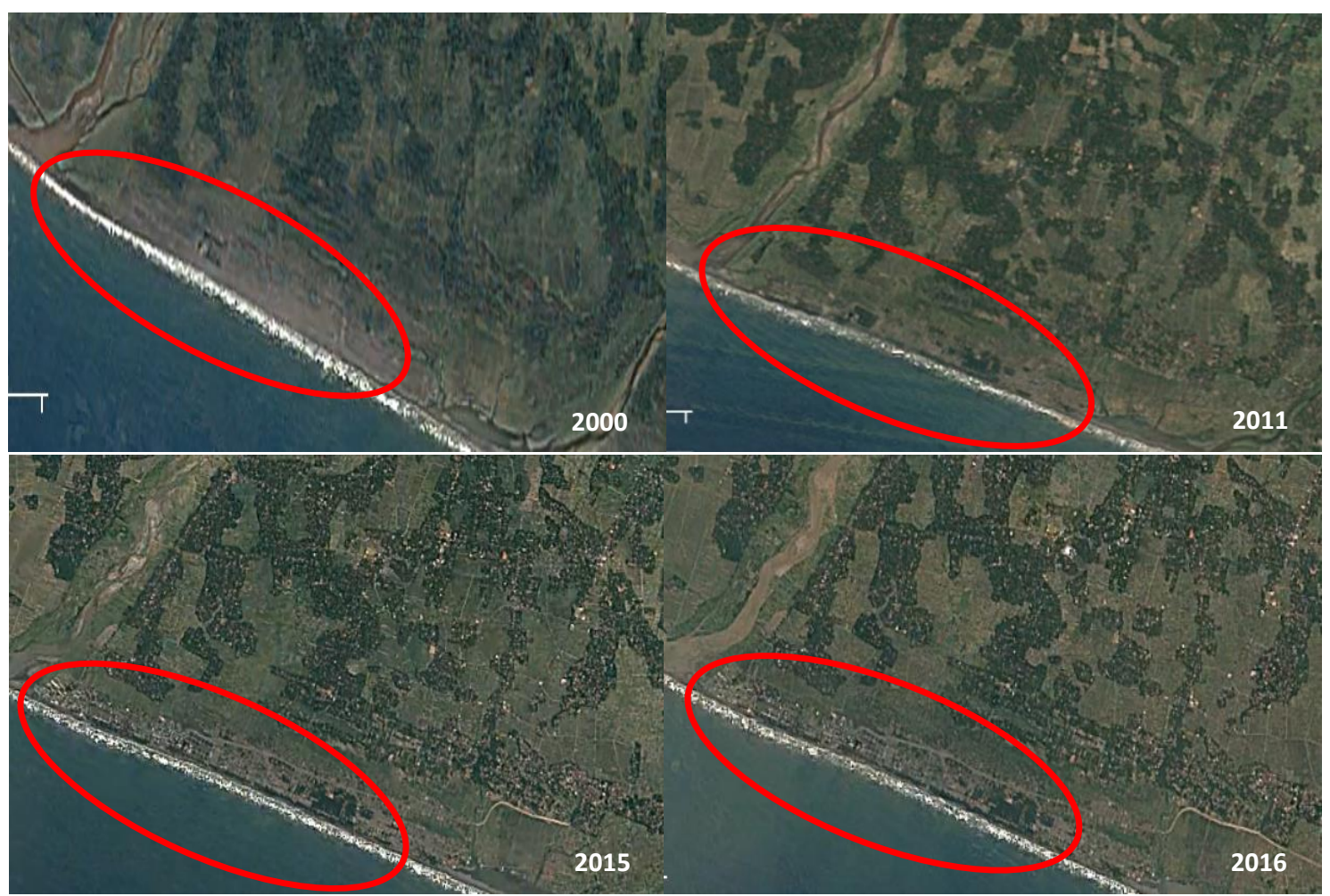

Figure 2. Land cover of coastal area of Bantul District, Yogyakarta, Indonesia please be clear. Through Google Timelapse from 2000, 2011,2015 and 2016

Table 2. Physical and chemical properties of soil from coastal areas of Bantul District, Yogyakarta, Indonesia

\begin{tabular}{|c|c|c|c|c|c|c|c|c|c|c|c|c|c|}
\hline \multirow{2}{*}{ Sample } & \multirow{2}{*}{ pH } & \multirow{2}{*}{$\begin{array}{c}\text { C-org } \\
(\%)\end{array}$} & \multirow{2}{*}{$\begin{array}{c}\mathrm{N} \\
(\%)\end{array}$} & \multirow{2}{*}{$\mathrm{C} / \mathrm{N}$} & \multirow{2}{*}{$\begin{array}{c}\mathbf{P}_{2} \mathbf{O}_{5} \\
(\mathbf{p p m})\end{array}$} & \multirow{2}{*}{$\mathbf{K}(\mathbf{p p m})$} & $\mathbf{C a}$ & Mg & $\mathbf{K}$ & $\mathrm{Na}$ & CEC & Sb & Salinity \\
\hline & & & & & & & \multicolumn{7}{|c|}{$(\mathrm{me} / \mathbf{1 0 0 g})$} \\
\hline T1S1 & 7.4 & 0.05 & 0.02 & 2 & 7.8 & 36.9 & 1.1 & 0.2 & 0.04 & 0.1 & 3.2 & 46 & 0.07 \\
\hline T1S2 & 8.8 & 0.10 & 0.01 & 12 & 6.1 & 31.8 & 0.6 & 0.3 & 0.09 & 0.1 & 2.3 & 48 & 0.035 \\
\hline T1S3 & 6.0 & 0.45 & 0.04 & 11 & 143.9 & 10.0 & 0.9 & 0.3 & 0.02 & 0.06 & 3.7 & 34 & 0.07 \\
\hline $\mathrm{T} 2 \mathrm{~S} 1$ & 6.4 & 1.56 & 0.18 & 9 & 73.9 & 125.1 & 23 & 10 & 0.37 & 1.0 & 37 & 95 & 0.37 \\
\hline $\mathrm{T} 2 \mathrm{~S} 2$ & 7.5 & 0.07 & 0.02 & 3 & 13.7 & 9.4 & 0.5 & 0.06 & 0.04 & 0.04 & 2.1 & 31 & 0.025 \\
\hline $\mathrm{T} 2 \mathrm{~S} 3$ & 7.3 & 0.36 & 0.02 & 15 & 21.4 & 14.5 & 2.5 & 0.7 & 0.02 & 0.14 & 4.6 & 74 & 0.05 \\
\hline
\end{tabular}

The southern coastal region of Bantul is suitable for development of various sectors such as agriculture, aquaculture and tourism. Google Timelapse revealed that in the year 2000, the land formerly dominant with sand dunes used by sea turtles as spawning ground has changed into coastal area planted with Casuarina equisetifolia, an association of mangrove, as a wind barrier and soil stabilizer. The land was then further converted into shrimp farming land, evidenced through satellite imagery monitoring via Google Timelapse. The shrimp ponds have been growing massively since 2011. Shrimp ponds dominated the coastal areas in 2015. In addition to shrimp farming, coastal areas are also planted with mangrove association tree species as wind barrier and as soil stabilizers. Mangrove association species planted in the region is $C$. equisetifolia.

\section{Land suitability}

Spatially, land suitability of the southern coastal area of Bantul District was estimated based on land characteristics.
Characteristics of land such as slope, soil texture, available soil water capacity, and soil effective depth can be measured or estimated. The data are used for interpretation and evaluation of land for certain commodities (Yusuf 2006). The coastal region of Bantul District is mostly flat with Alluvial, Regosol, and Grumosol soil types and moderate rainfall (Bappeda Bantul 2013). These parameters meet the requirements for paddy filed, nonpaddy fields, mangrove associations, and ponds. Data processing using GIS produced the output of land suitability map for each class. Results of laboratory analysis on soil physical and chemical properties are presented in Table 2.

Soil physical and chemical characteristics data were then inputted to obtained land suitability class for each sector (Figure 3 ) and land suitability maps for coastal area (Figure 4). 


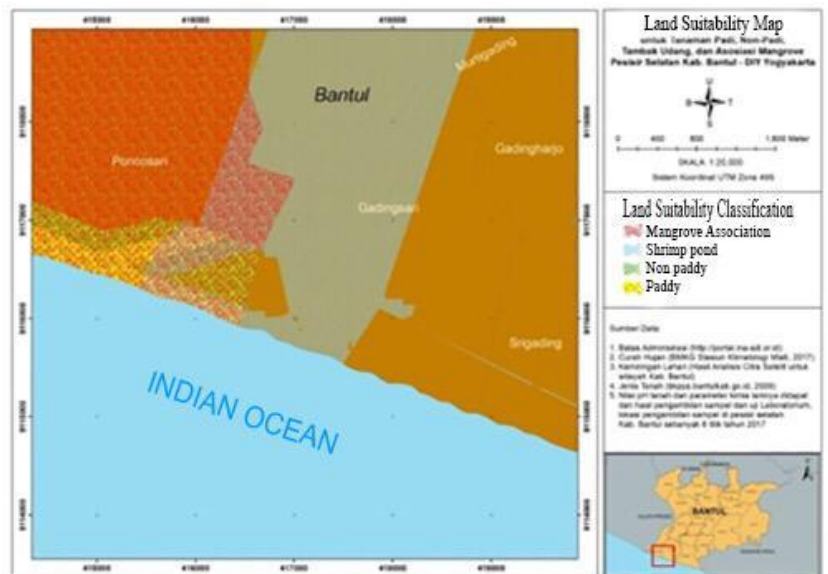

Figure 4. Land suitability map of South Coast of Bantul District, Yogyakarta, Indonesia

Measured soil $\mathrm{pHs}$ in the ponds were $\mathrm{pH}$ which is typical of saline soil variables. The soil $\mathrm{pH}$ values ranged from 6 to 8.8 which are suitable for agriculture or aquaculture. The C-organic ranged from 0.05-1.56. Corganic in the soil is important as it influences soil fertility. C-organic is produced by remaining plants or animals mixed with other mineral materials in the soil. C-organic has the function in suppression of erosion rates, penetration of $\mathrm{Al}$ and $\mathrm{Fe}$, and as energy sources for microorganisms. Corganic in the soil of South Coast of Bantul was relatively low due to the use of intensive synthesis chemicals. The optimal content of C-organic on good soil is $5 \%$. The soil total $\mathrm{N}$ were observed at 0.01 to 0.18 which is categorized as very low and low. Factors that affect the availability of $\mathrm{N}$ are microorganisms, both free-living and symbiotic with plants. Nitrogen can be absorbed through rainwater as nitrates. Nitrogen is an essential plant nutrition element as it functions to improve plant vegetative growth and protein formation. Carbon and nitrogen ratios or $\mathrm{C} / \mathrm{N}$ ratios can be used to determine the existence of plants because nitrogen is absorbed by plants and microorganisms, and microorganisms changed into carbon sediments. In addition, the $\mathrm{C} / \mathrm{N}$ ratio can also be used to determine climate conditions in the past. Phosphates in the soil on the southern coast of Bantul varied from 6.1 to 143.9, which are low to very high categories. Factors that influence the availability of phosphorus include: $\mathrm{pH}$, iron and soluble aluminum, the presence of minerals containing iron, aluminum, and manganese, calcium minerals, the amount of decomposition of organic matter and microorganism activities.
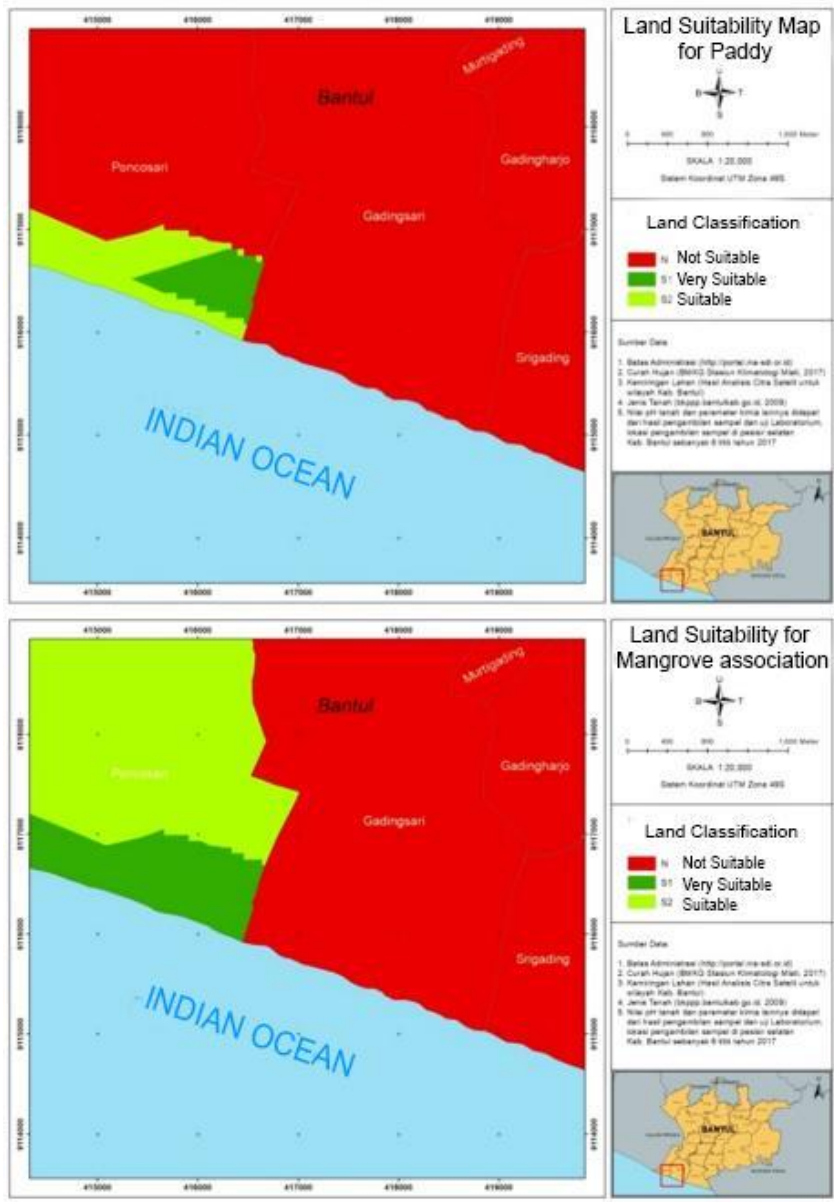
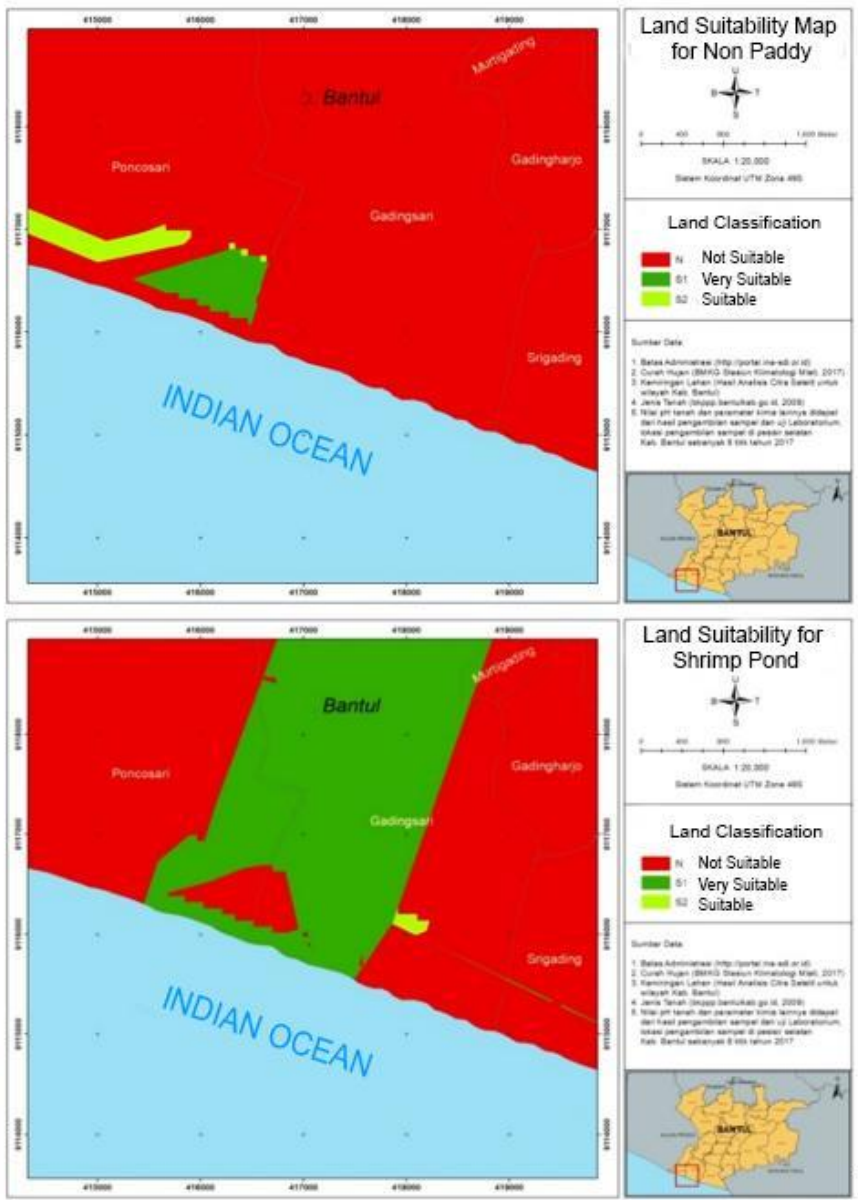

Figure 3. Land suitability for paddy, non-paddy (corn, onion, dragon fruit), mangrove association and shrimp pond 


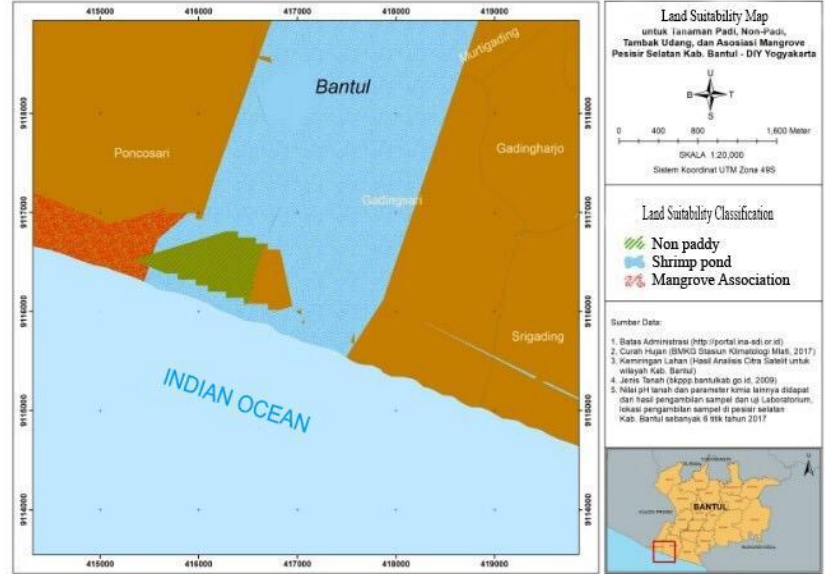

Figure 5. Land suitability map of Bantul District, Yogyakarta, Indonesia based on community verification and GIS

Soil $\mathrm{K}$ content in the coastal land of Bantul ranged from 0.53 to 23.24 (low to high) while the soil Ca ranged from 0.53 to 23.24 (low to high). The $\mathrm{Mg}$ on soil varied from 0.23 to $10.49 . \mathrm{Mg}$ is a base cation as with $\mathrm{Ca}, \mathrm{K}$ and $\mathrm{Na}$. The soil K (potassium) content varied from 9.4 (very low) to 125.1 (very high) while the Na varied from 0.04 to 1.03 . Sodium (Na) serves to improve plant growth if plants lack potassium. Soil samples analysis showed that the CEC ranged from 2.13 to 36.98 , indicating that the CEC on the coastal land of Bantul was categorized into very low to high. The range of $\mathrm{Sb}$ saturation base was 31-95, which means that the soil varies in fertility. Soil is classified highly fertile if the base saturation is $>80 \%$, medium fertility if base saturation is between $50-80 \%$, and infertile if base saturation is $<50 \%$. The soil salinity ranged from 0.025 to $0.37 \mathrm{dS} \mathrm{m}^{-1}$, which is in the low category $(<2 \mathrm{dS}$ $\left.\mathrm{m}^{-1}\right)$.

Physical and chemical data were then inputted through matching and scoring using Geographic Information System (GIS) to obtain land suitability map for each category (paddy field, non-paddy field, shrimp farm field, and mangrove association) (Figure 3 ).

The land suitability map (Figure 3) shows that the western coastal area (Pantai Baru Area) of Poncosari area is suitable for mangrove association plant with an area of 616.42 ha. Land suitable for rice crop only covers an area of 148.52 ha in the Poncosari coastal area. The non-rice farming area (84.32 ha) was categorized as 'suitable'. Suitable land for shrimp farms covers an area of 634.82 ha. The total coastal area used for above-mentioned sector activities was 1800.25 ha.

\section{Community perception of the identified land suitability classes}

The results showed that $64 \%$ of the respondents agreed to use the land as shrimp farming land, 59\% (neutral/not deciding) to utilize the land as rice farming land, $77 \%$ (agree) to use the land as farmland for non-rice farming, and 59\% (neutral/not deciding) to make the land as an area of mangrove association. Thus, it can be concluded that coastal area of Bantul District is dominantly suitable based on community perception to be utilized as agricultural field. The people in the research area have a perception that coastal land is optimal to be used as non-paddy farm and shrimp farmland. Land suitability map generated from biophysical analysis revealed overlaps among sectors. For the sake of decision-making purpose, the community was asked to select recommendations for the utilization of coastal land. Community perception and coastal land suitability map of Bantul District were used as considerations for decision making on future land use. A final land suitability map was obtained (Figure 5) based on GIS (Geographic Information System) and verification by the community. The coastal area of Poncosari is biophysically suitable for and was verified by the community as a land of mangrove association with an area size of 67.4 ha. Meanwhile, the coastal area of Gadingsari is suitable and verified by the community to be utilized as shrimp farmland and non-paddy agriculture, with land suitability for shrimp ponds of 607.6 ha and non-paddy farming of 50.1 ha. The eastern site of Srigading area was not suitable for shrimp farms, agriculture, and mangrove associations. Thus, the land is recommended to be used for tourism considering that the land has indeed been used for the tourism sector and turtle conservation.

\section{Discussion}

There has been a change of land cover seen from Google Timelapse in the forms of changes of natural land into agriculture starting from 2000 to 2011. Data processing image WorldView 2year 2017 with a $0.5 \mathrm{~m}$ panchromatic resolution and $1.8 \mathrm{~m}$ multispectral resolution indicated that the aquaculture activities have decreased in land coverage due to various diseases and management of shrimp ponds that do not meet the standards. Physical characteristics of the land suitability in the research area, i.e., most of the southern coastal district of Bantul, has the soil types of Regosol, Grumosol, and Alluvial, and the coastal area is dominantly flat slopes.

Meanwhile, the soil of Southern coastal of Bantul District was dominantly neutral in $\mathrm{pH}$, generally low in soil chemical properties such as salinity, $\mathrm{C}$-organic and total $\mathrm{N}$ contents, very low to medium in $\mathrm{C} / \mathrm{N}$ ratio, low to very high in both phosphorus and potassium contents, low to very high CEC, Base Saturation: not fertile to highly fertile, and low to high and macroelement content. The physical and chemical characteristics of the soil become the determinant parameters in determining the land suitability. The results showed that the southern coastal soil of Bantul had $\mathrm{pH}$ values from 6 to 8.8 that is suitable for agriculture. According to Djaenuddin (2000) and Kementan (2015), pH range of 6-9 is suitable for agriculture. The soil $\mathrm{pH}$ range of 6 to 8.8 is also suitable for aquaculture. $\mathrm{pH}$ range of 6.5-8.5 is suitable for shrimp aquaculture and mangrove association. Moreover, C-organic in the soil of south coastland of Bantul is relatively low, but the optimal content of C-organic on good soil must be $5 \%$ for agriculture. Low value of C-organic is suitable for shrimp aquaculture (Wibowo 2014). The N-total is on the very low and low category (Table 1), whereas $\mathrm{N}$ is necessary to 
produce protein for plants. However, very low Nitrogen could be suitable for paddy, non-paddy (corn, onion, dragon fruit) and shrimp aquaculture base on soil chemistry criteria of Pusat Penelitian Tanah (1983).

Phosphorus is important elements for plants growth (Hakim 1986). Phosphorus in the soil on the southern coast of Bantul varied from 6.1 to 143.9 in the low to very high category, and is suitable for agriculture and shrimp aquaculture. Another important element is $\mathrm{K}$ (potassium). Based on the results of soil samples testing, the results of $\mathrm{Ca}$ in the coastal land of Bantul are ranged from 0.53 to 23.24 (low to high) and most suitable for shrimp aquaculture.

With these physical and chemical characteristics, it can be concluded that the coastal area of Bantul District is suitable for shrimp aquaculture. Based on the results of land suitability analysis according to FAO in 1976, from 1800,25 ha of coastal area, that the dominant land is suitable shrimp pond and mangrove association. This is in accordance with the results of the perception and verification of coastal communities which agree that the coastal area of Bantul District can be used for shrimp farming and plantation of mangrove association species.

In conclusion, the results revealed that 634.82 ha area of the land was suitable for shrimp ponds and 84.32 ha area were suitable for non-paddy agriculture. Lands suitable for paddy field were about 148.58 ha, and that for mangrove plant association was 616.42 ha. Spatially, coastal area of Bantul District was dominantly suitable for shrimp farming. The land suitability map (Figure 4) will be a recommendation for communities in coastal land use.

\section{ACKNOWLEDGEMENTS}

I would like to express my deep gratitude to Dr. Endang Hernawan, and Dr. Tien Lastini for all kindly helps and motivation during this research.

\section{REFERENCES}

Aditiyas W. 2014. Scoring Technic for Spatial Analysis. Brawijaya University, Malang. [Indonesian]

Almulla L. 2013. Soil site suitability evaluation for mangrove plantation in Kuwait. World Appl Sci J 22 (11): 1644-1651, 2013. ISSN 18184952.

Ambarwati D. 2016. Technical Analysis and Business of Vaname Shrimp Farming (Litopeneaus vannamei) in Ponds in Bantul District Coastal. Gadjah Mada University, Yogyakarta. [Indonesian]
Arbaraka G. 2014. Shrimp pond, lichens in shrimp cauliflower at Samas, Special Region of Yogyakarta. [Thesis]. Gadjah Mada University, Yogyakarta. [Indonesian]

Bappeda 2013. Database Profil Daerah Kabupaten Bantul Tahun 2013. The Government of Bantul District, Yogyakarta. [Indonesian]

Biggs J, Williams P, Whitfield PN, Weatherby A. 2005. 15 years of pond assessment in Britain: Results and lessons.

BMKG. 2017. Buletin Prakiraan Curah Hujan Daerah Istimewa Yogyakarta. BMKG Yogyakarta, Yogyakarta, Indonesian. [Indonesian]

Deckers J, Spaargaren O. 2001. Lecture notes on the major soils of the world. World Soil Resources Reports: FAO; Vol. 94. Food and Agriculture Organization of the United Nations (FAO), Rome.

Dengiz O. 2013. Land suitability assessment for rice cultivation based on GIS modeling. Turk J Agric For 37 (3). Ondokuz Mayis Universitesi, Turkey.

Diaz I, Mello LA, Salhi M. 2016. Multiscalar land suitability assessment for aquaculture production in Uruguay. Aquac Res, Wiley Online Library.

FAO. 1976. A Frame Work for Land Evaluation (Soil Bulletin). Food and Agriculture Organization of the United Nations, Rome, Italy.

Gilman E. 2006. Pacific Island Mangroves in a Changing Climate and Rising Sea. UNEP, Kenya

Hadipour A, Vafaie F. 2014. Land suitability evaluation for brackish water aquaculture development in coastal area of Hormozgan, Iran. Aquac Int 23 (1): 329-343.

Hasanah I. 2013. Evaluation of appropriateness of traditional shrimp pond based on biophysics in Tritunggal, Lamongan District. Mspi Student Journal 1 (1): 11-21. [Indonesian].

Manjela G. 2010. Basic Training GIS Module. Tropenbos International Indonesia, Balikpapan, Indonesia. [Indonesian]

Nelson DW, Sommer LE. 1982. Total Carbon, Organic Carbon and Organic Matter. Methods of Soil Analysis, Part 2. Chemical and Microbiological Properties, 2nd Edition. ASA-SSSA, Madison, 595579.

Pratiwi R. 2009. The mangrove crabs (Crustacea: Decapoda) recorded in reference collection of Research Centre for Oceanografi-Indonesian Insitute of Sciences 1960-1970. LIPI, Jakarta, Indonesia. [Indonesian]

Priyono A. 2010. Practice Guide Mangrove Rehabilitation in Coastal Area of Indonesia. Kesemat UNDIP, Semarang, Indonesia. [Indonesian]

Simpson L. 2009. A Manual of soil conservation and slope cultivation. Caribbean Agricultural Research and Development Institute (CARDI), Belize.

Sosia. 2014. Mangroves of Siak and Meranti Islands. Environmental and Regulatory Compliance Division Safety, Health and Environment Department. Energi Mega Persada, Jakarta. [Indonesian]

Suprakto B, Soemarno, Marsoedi, Arfiati D. 2014. Development of mangrove conservation area based on land suitability and environment carrying capacity (Case study from Probolinggo coastal area, East Java, Indonesia). Int J Ecosyst 4 (3): 107-118.

Suyono DA. 2010. Phosphorus composition in paddy based on phosphorus fertilizers and organics. Bionatura-J Nat Sci Phys Vol. 12, No. 3, November 2010: 126-135 ISSN 1411 - 0903.

Teixeira E, Fischer G, Velthuizen H, Walter C, Ewert F. 2013. Global hot spots of heat on agricultural crops due to climate change. Agric Meteorol 170: 206-215. Elsevier.

WWF. 2014. Better Management Practices: Seri Panduan Perikanan Skala Kecil, Budidaya Udang Vannamei, Tambak Semi Intensif dengan Instalasi Pengolahan Air Limbah (IPAL) Versi 1. WWF Indonesia, Jakarta. [Indonesian]

Zafar MA, Haque MM, Aziz MSB, Alam MM. 2015. Study on water and soil quality parameters of shrimp and prawn farming in the Southwest Region of Bangladesh. J Bangladesh Agric Univ 13 (1): 153-160. 